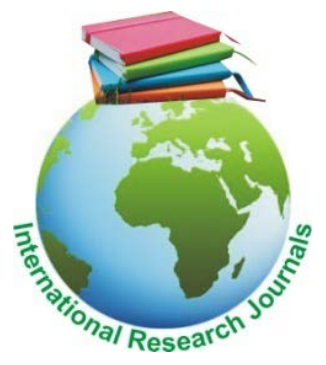

Rsearch Article

African Journal of Food Science and Technology (ISSN: 2141-5455) Vol. 9(3) pp. 48-51, Sep, 2018

DOI: http:/dx.doi.org/10.14303/ajfst.2018.235

Available online https://www.interesjournals.org/food-science-technology.html

Copyright (C2018 International Research Journals

\title{
Formulating a gelatine-free set yoghurt with Cyclea peltata
}

\author{
Pethmi Siriwardhana $^{1}$, Sharini C Somasiri ${ }^{1 *}$, Maharsha Edirisinghe ${ }^{2}$, Mahesh Vithanage ${ }^{2}$ \\ ${ }^{1}$ Department of Animal and Food Sciences, Faculty of Agriculture, Rajarata University of Sri Lanka, \\ Anuradhapura, Sri Lanka.sharinisc@yahoo.com \\ ${ }^{2}$ Milco (Pvt) Ltd, Narahenpita, Sri Lanka.
}

\begin{abstract}
Lacto vegetarians are reluctant to eat yoghurts due to gelatine as it is a non-vegan compound. Thus, this study was focused on developing a set yoghurt using Cyclea peltata leaf gel as a gelatine substitute. The gelatine was extracted by grinding the Cyclea peltata leaves. There were four recipes (four treatments) of set yoghurts prepared incorporating different levels $(0,4,6$ and $8 \mathrm{~g})$ of Cyclea peltata leaf gel per one litre of yoghurt mix. The other ingredients were used in similar proportions in all four treatments. The amount of gelatine in the control yoghurt was $6 \mathrm{gL}^{-1}$ with $0 \mathrm{gL}^{-1}$ Cyclea peltata leaf gel. The most effective two recipes were selected by undertaking a sensory evaluation, $\mathrm{pH}$, titratable acidity and coliform and yeast and mould counts. The selected two recipes were then analysed for nutrient content. Titratable acidity was not different in all four treatments. There were no coliforms present in all four treatments; neither the yeast nor mould present up to12 ${ }^{\text {th }}$ day of storage. Treatment with $6 \mathrm{gL}^{-1}$ of leaf gel had the highest sums of rank in the sensory evaluation test and the control had next best level. The nutrient content was not different between treatment with $6 \mathrm{gL}^{-1}$ of leaf gel and control except for crude fibre content. The treatment with $6 \mathrm{gL}^{-1}$ of leaf gel was selected as the best recipe considering the sensory evaluation results. Thus, it can be concluded that Cyclea peltata leaf gel can be used to replace gelatine in set yoghurt completely.

Keywords: Leaf gel, Sensory evaluation, Shelf life.
\end{abstract}

\section{INTRODUCTION}

At present consumers are more interested in "functional foods" that provide advantages other than nutritional benefits (Scrinis, 2008). Foods such as cheese, curd and yoghurts are known as health promoters as they are rich in probiotics, prebiotics, omega-3 fatty acids etc. Yoghurt is a highly demanded fermented dairy product in the world. The health benefits of yoghurts include; $a$ rich source of calcium, a probiotic carrier, help people to overcome lactose intolerance and alleviate gastro intestinal disorders (Weerathilake et al., 2014). Tamime and Deeth, (1980) stated that yoghurts can be divided into different groups according to the chemical composition, physical nature of the product, flavours added and postfermentation process. Gelatine is added to yoghurt to maintain the stability and in addition it is responsible for the smooth mouth feel and shiny appearance (Roa,
2014). However, gelatine used in yoghurts is produced from animal sources and the halal and vegan consumers are highly concerned. Further, the gelatine price itself is high and thus, the producers are looking for alternatives to replace gelatine either partially or completely in their yoghurt recipes (Mariod and Adam, 2013).

Cyclea peltata is a climbing shrub that belongs to Menispermaceae family. It is considered mainly as a medicinal herb in aesthetic medicine and its roots and leaves are used to treat various diseases including skin diseases, leprosy and cardiac disorders (Bedi et al., 2010; Savithramma et al., 2011; Singh and Nishteswar, 2013). The alkaloids present in the Cyclea peltata roots and leaves are responsible for treating above disease conditions (Singh and Nishteswar, 2013). Recently, it has been tried to use Cyclea peltata plant extract in yoghurt preparation in Sri Lanka (Ranathunga et al., 2017). 
Hence, a study was undertaken to find out whether the gelatine produced from Cyclea peltata could be used to replace the gelatine used in the production of set yoghurt either partially or totally. The research was funded by Milco (Pvt) Limited, Sri Lanka.

\section{MATERIALS AND METHODS}

\section{Experimental Location}

This research was carried out at the Milco (Pvt) Limited, Sri Lanka and at the Department of Animal and Food Sciences, Faculty of Agriculture, Rajarata University of Sri Lanka.

\section{Experimental Design and Treatments}

Experimental design was Complete Randomized Design (CRD) with four treatments and three replicates per treatment. The four treatments were given in Table 1.

Table 1. The treatments

\begin{tabular}{|c|c|}
\hline Treatment & g of Cyclea peltata leaf gel $\mathrm{L}^{-1}$ of Milk \\
\hline 1 & $\begin{array}{c}\text { Set yoghurt mixture including } 6 \mathrm{~g} \text { of gelatin }+0 \mathrm{~g} \text { of leaf } \\
\text { gel (Control) }\end{array}$ \\
\hline 2 & Set yoghurt mixture excluding gelatin $+4 \mathrm{~g}$ of leaf gel \\
\hline 3 & Set yoghurt mixture excluding gelatin $+6 \mathrm{~g}$ of leaf gel \\
\hline 4 & Set yoghurt mixture excluding gelatin $+8 \mathrm{~g}$ of leaf gel \\
\hline
\end{tabular}

Note: Set yoghurt mixture was provided by the Milco (Pvt) Limited, Sri Lanka

\section{Extraction of Cyclea peltata (common name: Raja Patha) Leaf Gel}

Cyclea peltata leaves were collected from Low Country Wet Zone Agro Ecological Zone (WL1a) of Sri Lanka (Punniyawardena, 2008). Leaves were cleaned by using distilled water to remove the adulterations. Afterwards the leaves were cut into smaller pieces and blended by adding $100 \mathrm{~mL}$ of water to extract the leaf gel. When blending the leaf pieces a gel was formed. This gel was squeezed out by using a clean cotton cloth. The collected gel was stored at $4^{\circ} \mathrm{C}$.

\section{Preparation of Treatment Yoghurts}

The treatment yoghurts were prepared at the Milco (Pvt) Ltd, Sri Lanka using the following steps showed in Figure 1.

${ }^{1}$ The ingredients in the starter culture was specific to the Milco (Pvt) limited, Sri Lanka

\section{Sensory Evaluation of Treatment Yoghurts}

Sensory evaluation was carried out to select the best concentration of Cyclea peltata leaf gel that can be incorporated into the yoghurt. Set yoghurts prepared incorporating Cyclea peltata leaf gel at a rate of $0 \mathrm{gL}^{-1}, 4$ $\mathrm{gL}^{-1}, 6 \mathrm{gL}^{-1}$ and $8 \mathrm{gL}^{-1}$ were used in the sensory evaluation. Yoghurts were marked with 3 digit code and followed by a sensory evaluation using 30 untrained panellists of

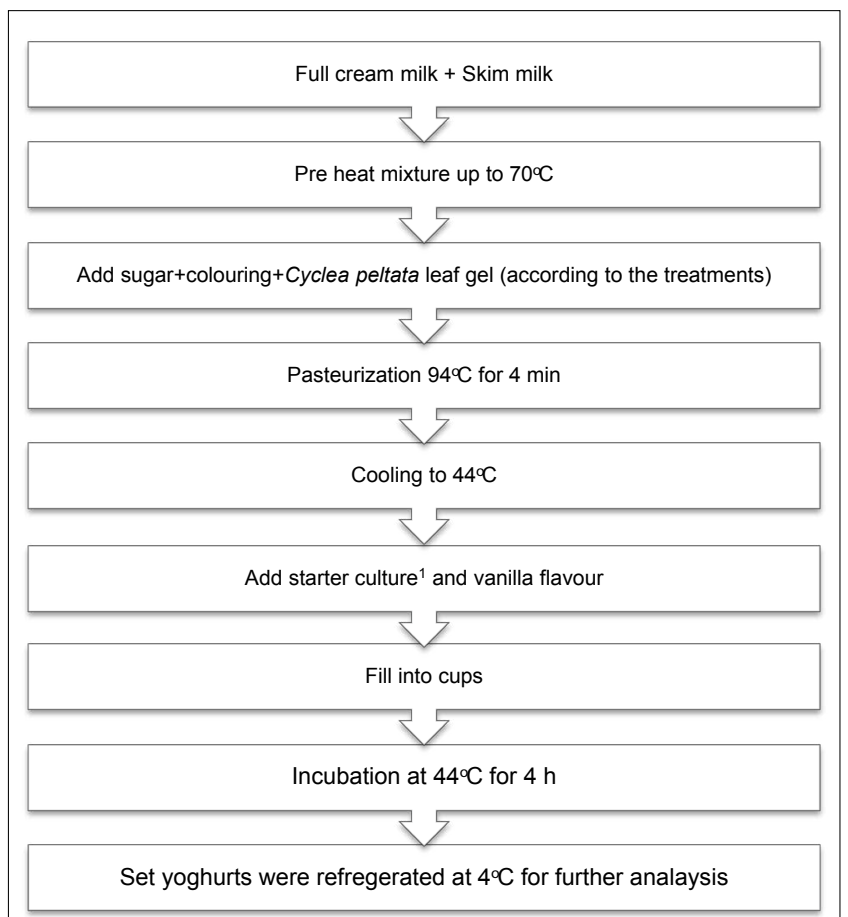

${ }^{1}$ The ingredients in the starter culture was specific to the Milco (Pvt) limited, Sri Lanka

Figure 1. Flow chart of the preparation of treatment yoghurts (Cyclea peltata gel incorporated set yoghurts)

judges from Faculty of Agriculture, Rajarata University of Sri Lanka. The panellists were asked to rate each sensory attribute (appearance, colour, spoon ability, flavour, mouth feel, after taste and overall acceptability) using a 'nine-point' hedonic scale.

\section{Evaluation of Shelf Life}

The shelf life of the selected treatments was evaluated based on physicochemical parameters such as $\mathrm{pH}$ and titratable acidity (AOAC, 1999) and microbial contamination (coliform and yeast \& mould counts). Coliform and yeast \& mould counts were measured according to Bartram and Ballance, (1996) and Annonimous (1989) respectively.

\section{Nutrient Content of the Treatment Yoghurts}

The selected treatments were analysed for moisture content, either extract (Soxhlet procedure), crude protein (Kjeldahl method), ash content (Dry ash method) and crude fibre content (Gravimetric method) according to AOAC, (1999).

\section{RESULTS AND DISCUSSION}

\section{Sensory Evaluation}

Estimated mean rank sums of sensory attributes namely appearance, colour, spoon-ability, flavour, mouth feel, after taste and overall acceptability of different Cyclea peltata leaf gel levels incorporated yoghurt samples are shown in Figure 2. 


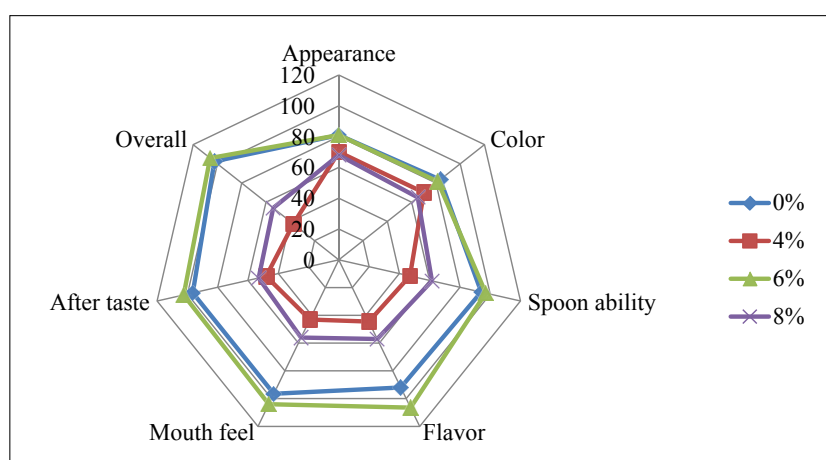

Figure 2. Pattern of variation of sensory properties in yoghurts.

When considering the four yoghurt treatments there was no difference $(P>0.05)$ in colour attribute between the four treatments. When considering appearance, there was no difference $(P>0.05)$ among four treatments. The spoon ability, flavour, mouth feel and after taste attributes of all yoghurt treatments, were different $(P<0.05)$ between the four treatments. Treatment 3 had the highest $(P<0.05)$ sums of rank for above attributes compared to treatment 1 (control) which in turn had a higher $(P<0.05)$ sums of rank than the other treatments. Highest $(P<0.05)$ sums of rank of 106 for overall acceptability was observed in treatment 3 ( $6 \mathrm{~g}$ leaf gel $\mathrm{L}^{-1}$ of yoghurt mix) while control ( $0 \mathrm{~g}$ leaf gel $\mathrm{L}^{-1}$ of yoghurt mix) had a score of 102.5 sums of rank. The overall acceptability score was lower $(P<0.05)$ for treatment 2 ( 4 g leaf gel $\mathrm{L}^{-1}$ of yoghurt mix) and treatment 4 ( $8 \mathrm{~g}$ leaf gel $\mathrm{L}^{-1}$ of yoghurt mix) compared to treatment 3 and control. The reason may be that the concentration of leaf gel is responsible for the syneresis which would directly related to the water holding capacity of the yoghurt as observed by Zainoldin and Baba, (2009). According to the above authors higher the syneresis, lower

Table 2. Changes of the $\mathrm{pH}$ of treatment yogurts and control during the storage period

\begin{tabular}{|l|c|c|c|c|c|}
\hline Treatment $^{1}$ & Day 01 & Day 04 & Day 08 & Day 12 & Day 15 \\
\hline T1 $\left(0 \mathrm{gL}^{-1}\right)$ & $4.63 \pm 0.35^{\mathrm{a}}$ & $4.6 \pm 0.35^{\mathrm{a}}$ & $4.47 \pm 0.35^{\mathrm{a}}$ & $4.2 \pm 0.35^{\mathrm{a}}$ & $4.17 \pm 0.35^{\mathrm{a}}$ \\
\hline T2 $\left(4 \mathrm{gL}^{-1}\right)$ & $4.57 \pm 0.35^{\mathrm{a}}$ & $4.45 \pm 0.35^{\mathrm{b}}$ & $4.40 \pm 0.35^{\mathrm{b}}$ & $4.2 \pm 0.35^{\mathrm{a}}$ & $4.14 \pm 0.35^{\mathrm{a}}$ \\
\hline T3 $\left(6 \mathrm{gL}^{-1}\right)$ & $4.56 \pm 0.35^{\mathrm{a}}$ & $4.44 \pm 0.35^{\mathrm{b}}$ & $4.36 \pm 0.35^{\mathrm{b}}$ & $4.17 \pm 0.35^{\mathrm{a}}$ & $4.11 \pm 0.35^{\mathrm{a}}$ \\
\hline T4 $\left(8 \mathrm{gL}^{-1}\right)$ & $4.55 \pm 0.35^{\mathrm{a}}$ & $4.43 \pm 0.35^{\mathrm{b}}$ & $4.35 \pm 0.35^{\mathrm{b}}$ & $4.13 \pm 0.35^{\mathrm{a}}$ & $4.08 \pm 0.35^{\mathrm{a}}$ \\
\hline
\end{tabular}

${ }^{1}$ Cyclea peltata leaf gel incorporated set yoghurt

a, b Differing superscripts within columns indicate means that were significantly different $(P<0.05)$. the water holding capacity. When the concentration of leaf gel was lower ( $4 \mathrm{~g}_{\text {leaf }} \mathrm{gel}^{-1}$ ) in the yoghurt, it may not have been enough to maintain the required level of syneresis and the water holding capacity.

\section{Shelf Life of the Treatment Yoghurts and Control}

pH: According to Table 2, during the storage period, $\mathrm{pH}$ gradually decreased in all four treatments. The acceptable range of $\mathrm{pH}$ for yoghurts in Sri Lanka is less than 4.5 (Annonimous, 1989). A lower $(P<0.05) \mathrm{pH}$ was observed in Cyclea peltata leaf gel added set yoghurts compared to control and when the proportion of leaf gel had been increased, $\mathrm{pH}$ further declined $(P<0.05)$. The accumulation of lactic acid may have contributed to the decrease in $\mathrm{pH}$ in the leaf gel incorporated yoghurts as observed by Tamime and Robinson, (2007).

Titratable acidity: During refrigerated storage condition, the titratable acidity gradually increased in all four treatments (Table 3 ). Titratable acidity during Day 12 was higher $(P<0.05)$ in treatment 4 compared to treatment 1 . Titratable acidity of treatments 2 and 3 was neither different $(P>0.05)$ from each other or with other treatments. Titratable acidity varied in the acceptable range of 0.8 (Annonimous, 1989) during the storage period.

The observed results in the present study are in agreement with Zainoldin and Baba, (2009), who observed that both $\mathrm{pH}$ and titratable acidity are key mechanisms of yoghurt fermentation. Sugar and protein contents in milk with the optimum incubation environment $\left(\mathrm{pH} 7\right.$ and $\left.41^{\circ} \mathrm{C}\right)$ are believed to promote the growth of culture bacteria Streptococcus thermophilus rapidly (Zainoldin and Baba, 2009). Reaction of S. thermophilus on milk sugar, lactic acid, acetaldehyde, diacetyl and formic acid are produced resulting post acidification during fermentation.

\section{Microbiological Assessment}

Coliform count: According to ISO 4832:2006 allowable limit for coliforms in yoghurt is less than $10 \mathrm{cfu}$ $\mathrm{g}^{-1}$. Coliform counts were not detected in Cyclea peltata leaf gel incorporated yoghurt (treatment 2, 3 and 4) or control yoghurt samples at refrigerated temperature $\left(4^{\circ} \mathrm{C}\right.$ $\pm 1^{\circ} \mathrm{C}$ ) during the storage period of 15 days. This indicates the hygienic measures that were undertaken during the production process were satisfactory (Igbabul et al., 2014).

Table 3. Changes of the TA of yoghurt samples during the storage period

\begin{tabular}{|c|c|c|c|c|c|}
\hline Treatment $^{1}$ & Day 01 & Day 04 & Day 08 & Day 12 & Day 15 \\
\hline $\mathrm{T} 1\left(0 \mathrm{gL}^{-1}\right)$ & $0.69 \pm 0.003^{a}$ & $0.75 \pm 0.003^{a}$ & $0.76 \pm 0.003^{a}$ & $0.81 \pm 0.003^{\mathrm{b}}$ & $0.85 \pm 0.003^{a}$ \\
\hline T2 $\left(4 \mathrm{gL}^{-1}\right)$ & $0.71 \pm 0.003^{a}$ & $0.75 \pm 0.003^{a}$ & $0.80 \pm 0.003^{a}$ & $0.83 \pm 0.003^{\mathrm{ab}}$ & $0.86 \pm 0.003^{a}$ \\
\hline T3 $\left(6 \mathrm{gL}^{-1}\right)$ & $0.72 \pm 0.003^{a}$ & $0.76 \pm 0.003^{a}$ & $0.80 \pm 0.003^{a}$ & $0.84 \pm 0.003^{\mathrm{ab}}$ & $0.86 \pm 0.003^{a}$ \\
\hline $\mathrm{T} 4\left(8 \mathrm{gL}^{-1}\right)$ & $0.73 \pm 0.003^{a}$ & $0.76 \pm 0.003^{a}$ & $0.82 \pm 0.003^{a}$ & $0.84 \pm 0.003^{a}$ & $0.86 \pm 0.003^{a}$ \\
\hline
\end{tabular}

${ }^{1}$ Cyclea peltata leaf gel incorporated set yoghurt

${ }^{\mathrm{a}, \mathrm{b}}$ Differing superscripts within columns indicate means that were significantly different $(P<0.05)$. 
Yeast and Mould: According to ISO 6611:2004, allowable limit for yeast is less than $50 \mathrm{cfu} \mathrm{g}^{-1}$ and mould is less than $1 \mathrm{cfu} \mathrm{g}^{-1}$. The yeast and mould counts did not $(P>0.05)$ exceed in the control and other treatment yoghurts beyond the allowable limits during the storage period. On the $12^{\text {th }}$ day of storage $20 \mathrm{cfu} \mathrm{g}^{-1}$ yeast count was observed in treatment 4 and on the $15^{\text {th }}$ day of storage $1 \mathrm{cfu} \mathrm{g}^{-1}$ mould count was observed in treatment 3. If the yeast and mould counts are beyond $100 \mathrm{cfu} \mathrm{g}^{-1}$ the yoghurts are considered unsuitable for consumption (Muir et al., 1993). Therefore, the observed results in the present study are within the acceptable range.

\section{Nutrient content of the treatment yoghurts:}

Table 4 shows that the nutritional properties of Cyclea peltata leaf gel incorporated treatment yoghurts and the control yoghurt. According to the results, moisture, ash, ether extract and crude protein contents did not $(P>0.05)$ show any difference between treatment and control yoghurts. Similar protein and either extract contents were obtained by Weerathilaka et al., (2014). However, crude fibre content was comparatively higher $(P<0.05)$ in leaf gel incorporated treatment yoghurts because of the fibrous nature of leaf gel. Igbabul, Shember, and Amove, (2014), observed a crude fibre content of $0.21-0.51 \%$ in commercial yoghurts prepared in Makurdi, Benue state, Nigeria. Crude fibre is an important nutrient for gastrointestinal and metabolic activity of human body (Schneeman, 2002). Thus, incooperating Cyclea peltata leaf gel in yoghurts provides both nutritional and health benefits.

Table 4. Nutrient Content of Treatment Yoghurts

\begin{tabular}{|l|l|l|l|l|l|}
\hline Treatment & Moisture & Ash & Fat & Crude fiber & Protein \\
\hline Control (T1) & $72.77 \pm 0.15^{\mathrm{a}}$ & $0.93 \pm 0.03^{\mathrm{a}}$ & $3.96 \pm 0.09^{\mathrm{a}}$ & $0.17 \pm 0.02^{\mathrm{a}}$ & $5.34 \pm 0.09^{\mathrm{a}}$ \\
\hline Selected (T3) & $72.82 \pm 0.15^{\mathrm{a}}$ & $0.82 \pm 0.03^{\mathrm{a}}$ & $4.05 \pm 0.09^{\mathrm{a}}$ & $0.27 \pm 0.02^{\mathrm{b}}$ & $5.17 \pm 0.09^{\mathrm{a}}$ \\
\hline
\end{tabular}

a, b Mean $\pm \mathrm{SE}(\mathrm{n}=3)$ not sharing same letter in each column is significantly $(P$ $\leq 0.05$ ) different from each other

\section{CONCLUSIONS}

According to the study Cyclea peltata leaf gel incorporated yoghurt could be prepared by incorporating $6 \mathrm{gL}^{-1}$ of leaf gel as a total substitute for gelatine in yoghurt preparation.

\section{REFERENCES}

Annonimous (1989). Sri Lanka Standards specification for fermented milk products.part 2 : yoghurt. SLS 824 . Sri Lanka Standards. Colombo 08, Sri Lanka.

AOAC (1999). Official Methods of Analysis (16th ed.) Association of Official Analytical Chemists (AOAC), Washington DC, USA.

Bartram J, Ballance R(1996). Water quality monitoring: A practical guide to the design and implementation of freshwater quality studies and monitoring programs. United Nations Environment Programme (UNEP) and the World Health Organization (WHO).
Bedi S, Tanuja, Vyas S (2010). Handbook of Aromatic and Essential Oil Plants, Agrobios, India pp 598.

Igbabul B, Shember J, Amove J (2014). Physicochemical, microbiological and sensory evaluation of yoghurt sold in Makurdi metropolis. Afr. J. Food Sci. Technol. 5(6): 129-135.

Mariod AA, Adam HF (2013). Review: Gelatin, Source, Extraction And Industrial Applications. Acta Sci. Pol. Technol. Aliment. 12(2): 135-147.

Muir DD, J Bruce J and AY Tamime (1993). Ovine milk: 4. Seasonal changes in microbiological quality of raw milk and yoghurt. Milchwissenschaft.

Punniyawardena BVR (2008). Rainfall pattern in Sri Lanka and agro-ecologocal zones. Department of Agriculture, Sri Lanka. Pp. 25-75.

Ranathunga RADD, Perera MNP, Deshapriya RMC (2017). Possibility of using Cyclea peltata plant extract as a substitute for Gelatin in set yoghurt (Abstract). 69th Annual Scientific Sessions of the Sri Lanka Veterinary Association: 37.

Roa B (2014). Formulating gelatin-free yogurt with a new cost-effective ingredient.

Savithramma, N, ML Rao and D Suhrulatha (2011). Screening of medicinal plants for secondary metabolites. Middle. East. J. Sci. Res. 8(3): 579-584.

Schneeman BO (2002). Gastrointestinal physiology and functions. Br. J. Nutr. 88(2): 159-163.

Scrinis G (2008). Functional foods or functionally marketed foods? A critique of and alternatives to, the category of 'functional foods'. Public. Health. Nutr. 11(5): 541-545.

Singh S, Nishteswar K (2013). Review on Cissampelos Pareira \& Cyclea Peltata (Patha Dwaya)-PhytoPharmacological Perspectives. Int. J. Ayurveda. Med. 4(4).

Tamime AY, Deeth HC (1980). Yogurt: Technology and Biochemistry. J. Food. Prot. 43(12): 939-977.

Tamime AY, Robinson RK (2007). Tamime and Robinson's yoghurt: science and technology. ( $3^{\text {rd }}$ eds.) Cambridge, Woodhead publishing limited and CRC press LLC.

Weerathilake WADV, Rasika DMD, Ruwanmali JKU, Munasinghe MADD (2014). The evolution, processing, varieties and health benefits of yogurt. Int. J. Sci. Res. pub. 4(4): 1-10.

Zainoldin KH, Baba AS (2009). The effect of hylocereus polyrhizus and hylocereus undatus on physicochemical, proteolysis, and antioxidant activity in yogurt. World. Acad. Sci. Eng. Technol. 3(12): 60. 